\title{
Trucking, Owner-Operators, and Florida Perishables ${ }^{1}$
}

Richard Beilock ${ }^{2}$

\section{Introduction}

Florida is the nation's second largest producer of fresh fruits and vegetables. The state also ranks second with regard to ornamentals. The large majority of these products are marketed outside the state. In excess of $99 \%$ of these goods are shipped by truck (USDA, 2003). Owner-operators, who both own and drive their trucks, are the smallest of trucking firms.

In the early 1980s, owner-operators accounted for just over half of all interstate movements of Florida's produce/ornamentals (Beilock and Fletcher, 1983). During the past two decades, trucking deregulation and technological developments have favored larger carriers, which may have caused the importance of owner-operators to decline. In this report, we examine the extent to which owner-operators have been able to maintain their share of Florida's produce/ornamentals haulage and their dependence upon larger carriers to secure loads.

\section{Owner-Operators}

Despite concerns that owner-operator numbers have declined, both absolutely and relative to larger carriers, the share of Florida produce/ornamentals they haul has actually increased. In 1982/1983, owner-operators accounted for $53 \%$ of produce/ornamentals shipments exiting the Florida Peninsula. In a 2001/2002 survey (Appendix; Beilock 2004), $57 \%$ of the trucks were driven by owner-operators (Figure 1).
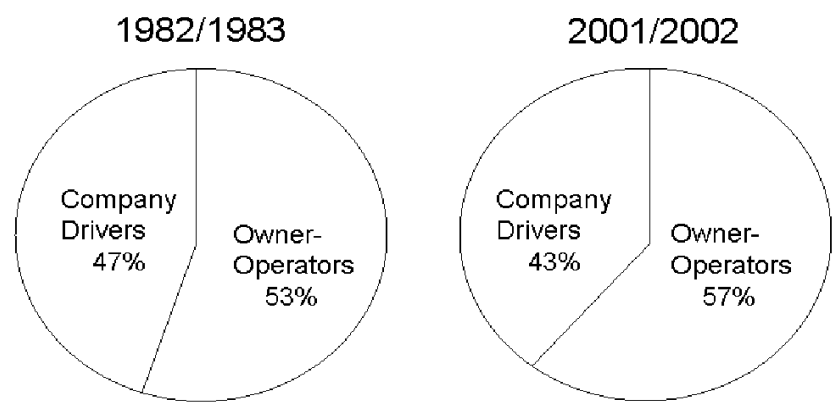

Figure 1. Percentage of owner-operators and company drivers, 1982/1983 and 2001/2002.

A large majority of these owner-operators have considerable experience in trucking and are devoted to the profession. The average owner-operator has been driving for 19.3 years and has been an owner-operator for 11.2 years. In addition, when asked if they would still be driving in five years, only $10 \%$ indicated they would not.

\section{Leasing to Larger Carriers}

The continued importance of owner-operators in produce/ornamentals haulage suggests that, at least in

1. This is EDIS document, FE543, a publication of the Department of Food and Resource Economics, Florida Cooperative Extension Service, Institute of Food and Agricultural Sciences, University of Florida, Gainesville, FL. Published March 2005. Please visit the EDIS website at http://edis.ifas.ufl.edu.

2. Richard Beilock, Professor, Department of Food and Resource Economics, Florida Cooperative Extension Service, Institute of Food and Agricultural Sciences, University of Florida, Gainesville, FL.

The Institute of Food and Agricultural Sciences is an equal opportunity/affirmative action employer authorized to provide research, educational information and other services only to individuals and institutions that function without regard to race, color, sex, age, handicap, or national origin. For information on obtaining other extension publications, contact your county Cooperative Extension Service office. Florida Cooperative Extension Service/Institute of Food and Agricultural Sciences/University of Florida/Christine Taylor Waddill, Dean. 
this segment of the motor carrier industry, the events of the past two decades have not eroded the competitive positions of small trucking firms. With regard to haulage of produce this is probably an accurate conclusion. Produce is usually moved in truckload or near-truckload shipments, and both small and large carriers normally deal directly with shipper/receivers or their representatives (Beilock, MacDonald, and Powers, 1988). However, produce haulers must also haul other types of cargoes to avoid excessive amounts of empty movements. For example, in a 2001/2002 survey (Beilock, 2004), drivers were asked what they were carrying when they entered Florida. Four out of five of those with loads were carrying neither produce nor ornamentals.

In some instances smaller carriers secure loads from larger carriers through trip or permanent leases. Under a trip (i.e., less than 30 days) or permanent (i.e., 30 days or more) lease, one carrier leases its services to another carrier. In some cases the carrier also owns the load (i.e., a private carrier). Leasing can be advantageous for owner-operators if larger carriers have comparative advantages with regard to marketing. In addition, leasing can give owner-operators access to long-distance terminal-to-terminal hauls (called linehauls) for less-than-truckload movements. While, legally, a carrier under lease is still an independent firm, in many regards, it is little more than part of the lessor's fleet. While a lessee (carrier under a lease) makes his own decisions regarding equipment maintenance and replacement and tags and taxes, he hauls loads at the direction and in the name of a lessor, making him subject to a lessor's rules on routings and driving times and speeds. As such, a fuller picture of the degree to which owner-operators are maintaining their positions can be obtained through examining their reliance on leasing.

Leasing has become much more common. In the $1982 / 1983$ survey, $35 \%$ of the owner-operators were operating under a lease agreement. In contrast, $65 \%$ of the owner-operators were under a lease in the 2001/2002 survey (Figure 2). One reason may be that larger carriers are better able to exploit new technologies to provide Just-in-Time, Electronic Data Interchange, and other services that are increasingly demanded by shipper/receivers. Moreover, larger carriers may utilize leasing as a strategy to minimize fixed and quasi-fixed costs, facilitate more rapid expansions and contractions in capacity, and reduce reliance on unionized labor (Belzer, 2000).
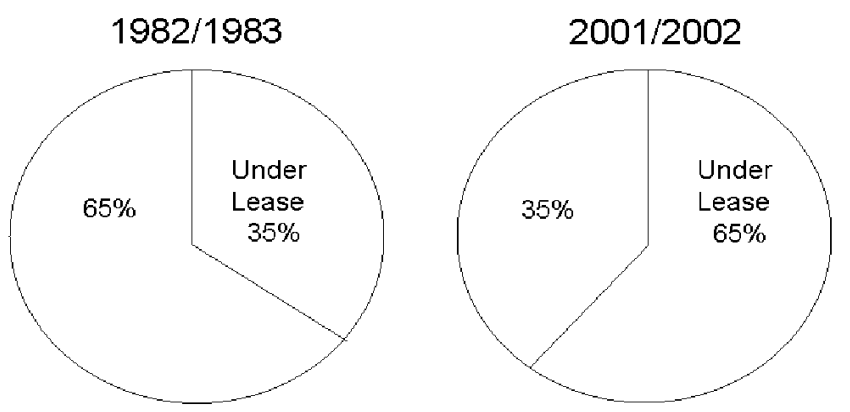

Figure 2. Percentage of owner-operators under lease, $1982 / 1983$ and 2001/2002.

The usefulness of leasing for securing loads is indicated by the fact that just under $5 \%$ of the owner-operators with leases entered Florida without a load versus $11 \%$ of the owner-operators without leases. These differences were smaller with respect to movements out of Florida ( $9 \%$ and $12 \%$ empty, respectively).

Particularly, if owner-operators are able to move readily from one lessor to another while operating independently, leasing can be an efficient way for owner-operators to access marketing and other services that would be difficult for them to provide and for larger carriers to maintain flexibility for their fleets. On the other hand, it may be indicative of reduced profitability and flexibility for owner-operators.

Whatever the ramifications of increased reliance on leasing may be, the results suggest that this trend is continuing. Comparing owner-operators with leases to owner-operators without leases reveals that the former have been owner-operators for a shorter time (9.9 versus 14 years). Those with leases $(50 \%)$ have been owner-operators for five years or less versus those without leases (29\%).

\section{Summary}

Florida relies heavily on trucking for interstate shipments of its produce/ornamentals. Twenty years ago, owner-operators accounted for just over half of 
this haulage. They still do. In 2001/2002, 57\% of all produce and ornamentals trucked out of the Florida Peninsula was by owner-operators.

A significant change over this period has been a near doubling of owner-operators' reliance on leasing to secure loads. It is uncertain whether this is other carriers acting as de facto dispatchers for shippers or a reduction in operational independence of owner-operators.

\section{References}

Beilock, R. 2004. Long Distance Refrigerated Trucking: A Florida Case Study. Report prepared for the Agricultural Marketing Service, United States Department of Agriculture, Washington, D.C.

Beilock, R., G. Fletcher Beilock, R., and G. Fletcher. 1983. Exempt Agricultural Commodity Haulers. Transportation Research Forum 24(1):444-450.

Beilock, R., J. MacDonald, and N. Powers. 1988. An Analysis of Produce Transportation: A Florida Case Study. ERS/USDA Agricultural Economic Report 597, Washington, D.C., 43 pp.

Belzer, M. 2000. Sweatshops on Wheels: Winners and Losers in Trucking Deregulation Oxford, UK: Oxford University Press.

United State Department of Agriculture. Various years. Fresh Fruit and Vegetable Shipments by Commodities, States, and Months, volumes 1970-2002. Agricultural Marketing Service, United States Department of Agriculture, Washington D.C.

\section{Appendix: Data}

The 2001/2002 Driver Survey: This survey was conducted in November of 2001, and in January, March, and May of 2002. The survey sites included the Florida Agricultural Inspection Stations located on interstate highways U.S. I-10, U.S. I-75, and U.S. I-95. The drivers of 1,642 refrigerated tractor-trailers were interviewed as they exited the Florida Peninsula.

While the survey sites were all in Florida, the study has relevance for long-distance haulage throughout North America. The sample contained drivers from all 48 contiguous U.S. states and 8 Canadian provinces. These drivers were enroute to destinations in 46 states, the District of Columbia, and 7 Canadian provinces. Trip distances ranged from 100 to 3,347 miles, averaging 1,222 miles. 